University of Nebraska - Lincoln

DigitalCommons@University of Nebraska - Lincoln

Other Publications in Zoonotics and Wildlife

Disease

Wildlife Disease and Zoonotics

2004

\title{
A processed pseudogene contributes to apparent mule deer prion gene heterogeneity
}

Kelly A. Brayton

Washington State University

Katherine I. O'Rourke

U.S. Department of Agriculture, katherine.orourke@ars.usda.gov

Amy K. Lyda

U.S. Department of Agriculture Research Service

Michael W. Miller

Wildlife Research Center

Donald P. Knowles Jr.

Washington State University, Don.Knowles@ARS.USDA.GOV

Follow this and additional works at: https://digitalcommons.unl.edu/zoonoticspub

Part of the Veterinary Infectious Diseases Commons

Brayton, Kelly A.; O'Rourke, Katherine I.; Lyda, Amy K.; Miller, Michael W.; and Knowles, Donald P. Jr., "A processed pseudogene contributes to apparent mule deer prion gene heterogeneity" (2004). Other Publications in Zoonotics and Wildlife Disease. 109.

https://digitalcommons.unl.edu/zoonoticspub/109

This Article is brought to you for free and open access by the Wildlife Disease and Zoonotics at DigitalCommons@University of Nebraska - Lincoln. It has been accepted for inclusion in Other Publications in Zoonotics and Wildlife Disease by an authorized administrator of DigitalCommons@University of Nebraska Lincoln. 


\title{
A processed pseudogene contributes to apparent mule deer prion gene heterogeneity
}

\author{
Kelly A. Brayton ${ }^{\mathrm{a}, *}$, Katherine I. O’Rourke ${ }^{\mathrm{b}}$, Amy K. Lyda ${ }^{\mathrm{b}}$, \\ Michael W. Miller ${ }^{\mathrm{c}}$, Donald P. Knowles Jr. ${ }^{\mathrm{a}, \mathrm{b}}$ \\ ${ }^{a}$ Department of Veterinary Microbiology and Pathology, Washington State University, Pullman, WA 99164-7040, USA \\ ${ }^{\mathrm{b}}$ Animal Disease Research Unit, USDA Agricultural Research Service, Pullman, WA 99164-7030, USA \\ ${ }^{\mathrm{c}}$ Colorado Division of Wildlife, Wildlife Research Center, Fort Collins, CO 80526-2097, USA
}

Received 10 July 2003; received in revised form 16 October 2003; accepted 27 October 2003

Received by D.A. Tagle

\begin{abstract}
Pathogenesis and transmission of the prion disorders (transmissible spongiform encephalopathies, TSEs) are mediated by a modified isoform of the prion protein (PrP). Prion protein gene (PRNP) alleles associated with relative susceptibility to TSE have been identified in sheep, humans and possibly elk. Comparable data have not been derived for mule deer, a species susceptible to the TSE chronic wasting disease (CWD). Initial analysis of the open reading frame (ORF) in exon 3 of the mule deer PRNP gene revealed polymorphisms in all 145 samples analyzed, with 10 potential polymorphic sites. Because 144/145 (99.3\%) of the samples were heterozygous for a coding change (N/ S) at codon 138 (bp 412) and a non-coding polymorphism at bp 418, and individual deer with three or four different alleles were identified a possible gene duplication was indicated. Analysis of BAC clones containing mule deer PRNP genes revealed a full length functional gene and a processed pseudogene. The pseudogene was characteristic of previously described retroelements, in that it lacks introns and is flanked by repeat sequences. Three alleles of the functional gene were identified, with coding changes only at codons 20 (D/G) and 225 (S/F). Determination of PRNP functional gene alleles from 47 CWD-positive mule deer showed the predominant allele encoded 20D225S (frequency 0.85 ). When alleles were grouped by coding changes in the functional gene, four of the six possible peptide combinations were identified in infected deer. Three pseudogene alleles with coding changes in exon 3 were identified in the mule deer samples examined. Because the TSEs appear to be "protein only" disorders, the presence of an untranslated pseudogene is not expected to affect disease resistance. Therefore, selection of a genotyping method specific for the functional gene is critical for large-scale studies to identify the role of the PRNP gene in susceptibility to CWD in mule deer.
\end{abstract}

(C) 2003 Published by Elsevier B.V.

Keywords: Chronic wasting disease; Brain; Spongiform encephalopathy

\section{Introduction}

Transmissible spongiform encephalopathies (TSEs) are a heterogeneous group of fatal neurodegenerative disorders reported in humans, sheep, cattle, mink and several species of deer and elk. The TSEs differ in etiology, host range, transmission routes, and clinical course, but all are charac-

Abbreviations: PRNP and PrP, prion protein; CWD, chronic wasting disease; TSE, transmissible spongiform encephalopathy; ORF, open reading frame.

* Corresponding author. Tel.: +1-509-335-6340; fax: +1-509-3358529.

E-mail address: kbrayton@vetmed.wsu.edu (K.A. Brayton). terized by accumulation of an abnormal isoform $\left(\operatorname{PrP}^{\mathrm{D}}\right)$ of a cellular sialoglyoprotein, the prion protein $\left(\mathrm{PrP}^{\mathrm{C}}\right)$ (Bolton et al., 1982). Protease resistant $\operatorname{PrP}^{\mathrm{D}}$ is found in infectious tissue extracts and is thought to be a major component of the transmissible agent, catalyzing the conversion of endogenous $\operatorname{PrP}^{\mathrm{C}}$ to $\operatorname{PrP}^{\mathrm{D}}$ in the susceptible host (Prusiner, 1982). The primary sequence of the host $\operatorname{PrP}^{\mathrm{C}}$ molecule is associated with relative susceptibility to acquired TSE in sheep (reviewed by Hunter, 1997), humans (Windl et al., 1996), and possibly in elk (O'Rourke et al., 1999) and is associated with clinical presentation in several human familial TSEs (Puoti et al., 2000).

Chronic wasting disease (CWD) is a TSE of free-ranging and captive North American cervid ruminants (Williams and 
Young, 1980, 1982, 1993; Spraker et al., 2002), affecting mule deer (Odocoileus hemionus), white-tailed deer (Odoocoileus virginianus) and elk (Cervus elaphus nelsoni). Clinical signs include weight loss, behavioral changes, polydipsia and polyuria, and excessive salivation (Williams and Young, 1982). Pathological changes in the central nervous system include spongiform encephalopathy and neuronal degeneration (Williams and Young, 1993). First reported in captive mule deer from a small region of the Western United States (Williams and Young, 1980), CWD has been endemic in contiguous areas of Colorado and Wyoming for more than 30 years (Miller et al., 2000; Williams and Miller, 2002) with more recent reports of disease in free ranging deer in Nebraska, South Dakota, Wisconsin, Illinois and New Mexico. This apparent increase in the CWD-affected areas has resulted in eradication programs that include attempts to depopulate target zones and infected captive herds, reduce congregations of deer at artificial feeding stations, and control interstate movement of captive deer or elk. Although there is no evidence that CWD has crossed the species barrier to cattle or humans (Raymond et al., 2000; Belay et al., 2001; Ward, 2003), perceived concerns about food safety have led to a call for eradication of all TSEs from food producing animals. Control of the ovine TSE, scrapie, includes selection of genetically resistant breeding stock (Dawson et al., 1998). The organization and sequence of the ovine PRNP gene have been reported (Westaway et al., 1994; Lee et al., 1998) and alleles associated with disease resistance have been described (reviewed in Hunter et al., 2000). Comparable data on the cervid PRNP gene have not been reported. In this study, we characterized the PRNP gene from mule deer, identified alleles found in CWD-susceptible individuals, and discovered a novel processed PRNP pseudogene in two subspecies of North American deer.

\section{Materials and methods}

\subsection{Animals}

Tonsil was collected from 117 clinically normal hunter killed mule deer from the CWD endemic area in Colorado, including 28 deer with evidence of $\operatorname{PrP}^{\mathrm{D}}$ detected by immunohistochemistry (from the study described in O'Rourke et al., 2003). Brain was collected from a sample of CWD-positive captive mule deer $(n=19$, from the study described in Wild et al., 2002) and blood was collected from CWD-positive live deer $(n=9)$ diagnosed by tonsil biopsy as described by Miller and Williams (2002). In addition, brain samples were collected from 13 captive reindeer (Rangifer tarandus) and 13 captive fallow deer (Cervus dama) from southwestern Nebraska (within the Nebraska CWD endemic area) and three captive Rocky Mountain elk from the Alberta province in Canada. Blood samples were collected from three black tailed deer (a subspecies of $O$. hemionus) from Washington state (an area with no reported CWD).

\subsection{Preparation of DNA and RNA}

DNA was isolated from $25 \mathrm{mg}$ of tissue using the Fast DNA kit (Q-BIOgene) kit or from $3 \mathrm{ml}$ aliquots of blood using the PureGene kit (Gentra), following the manufacturers' protocols. RNA was isolated from fresh blood samples or from buffy coat cells held at $-80{ }^{\circ} \mathrm{C}$, using the Qiagen Rneasy mini kit. Total RNA was used to prepare cDNA using the PRNP gene specific reverse transcription primer 314 which is located near the $3^{\prime}$ end of the open reading frame (ORF) in exon 3 corresponding to the complement of the region encoding residues 248-254 (all primers and probes are listed in Table 1) and the BRL superscript II kit using the conditions specified by the manufacturer.

\subsection{PCR and sequence analysis of genomic DNA and $c D N A$}

Genomic or cDNA was used as a template in PCR using primer set 199/202 (primer set 2 in Raymond et al., 2000) to amplify all alleles in mule deer (corresponding to ORF residues 23-231), primer set 223/224 to amplify only the functional gene alleles, or primer set 369/224 to amplify only the pseudogene alleles. Primer 223 anneals to sequences in intron 2 and primer 369 anneals to a sequence similar to exon 2 of the functional gene (differing by $2 \mathrm{bp}$ ). Primer 224 anneals to a sequence 7 bp downstream from the TAG stop codon in exon 3. Using the PCR conditions described below, primer pair 223/224 is specific for the ORF in exon 3 of the functional gene and primer pair 369/224 is specific for the same region of the pseudogene, which lacks intron 2. Reaction conditions were as follows: $95{ }^{\circ} \mathrm{C}, 5 \mathrm{~min}$ followed by 30 cycles of denaturation $\left(95{ }^{\circ} \mathrm{C}, 30 \mathrm{~s}\right)$, annealing $\left(54{ }^{\circ} \mathrm{C}, 30 \mathrm{~s}\right)$, and extension $\left(72{ }^{\circ} \mathrm{C}, 59 \mathrm{~s}\right)$ followed by an extension cycle $(72$ ${ }^{\circ} \mathrm{C}, 7 \mathrm{~min}$ ). PCR amplicons were treated with ExoSAP (USB) and directly sequenced using Big Dye chemistry (PE-Applied Biosystems) using forward primers 241 and 353 and reverse primers 12 and 350 , and analyzed on an ABI 377XL-96 instrument (PE-Applied Biosystems). PCR amplicons were cloned using the TA-TOPO cloning system (Invitrogen) and sequenced with primers $\mathrm{T} 3$ and $\mathrm{T} 7$ to confirm the sequence of each functional and each pseudogene allele.

\subsection{Library construction and screening}

Five grams of brain from mule deer no. 115-31 was pulverized with a mortar and pestle and the powdered tissue was embedded in agarose plugs. Cells were lysed within the agarose blocks using proteinase $\mathrm{K}$ and SDS (Birren et al., 1997). Genomic DNA was partially digested 
Table 1

Oligonucleotides used in this study

\begin{tabular}{|c|c|c|}
\hline Name & Sequence $5^{\prime} \rightarrow 3^{\prime}$ & Purpose \\
\hline 12 & GGTGGTGACTGTGTGTTGCTTGA & Sequencing primer \\
\hline 199 & CTGCAAGAAGCGACCAAAACC & PCR: functional and pseudogenes \\
\hline 202 & CACAGGAGGGGAGGAGAAGAGGAT & PCR: functional and pseudogenes \\
\hline 223 & ACACCCTCTTTATTTTGCAG & PCR: functional gene specific \\
\hline 224 & AGAAGATAATGAAAACAGGAAG & PCR: functional and pseudogenes \\
\hline 245 & GGCAACCGCTATCCACCTCA & Sequencing primer \\
\hline 247 & ATG GTG AAA AGC CAC ATA GGC AG & PCR: functional and pseudogenes \\
\hline 314 & ACTATGAGAAAAATGAGGAAAGAG & Reverse transcriptase primer \\
\hline 350 & TCCACTGACTGTGGGTACCACCTT & Sequencing primer \\
\hline 353 & AGCAACACACAGTCACCACCA & Sequencing primer \\
\hline 369 & CAACCAAGTCGAAGCATCT & PCR: pseudogene specific \\
\hline $529 \mathrm{gw} 1$ & AAAGCATCCAGAATTAGTTG & Sequence pseudogene \\
\hline $529 \mathrm{gw} 2$ & AAAGTCCTTGGTGAAATGAA & Sequence pseudogene \\
\hline $512 \mathrm{gw} 1$ & CACTCAATATGCCCAACAAA & Sequence pseudogene \\
\hline $512 \mathrm{gw} 2$ & TCGCAGAGGCAGGACTTC & Sequence pseudogene \\
\hline $512 \mathrm{gw} 4$ & ACAACTCGCTCCATCATC & Sequence pseudogene \\
\hline $512 \mathrm{gw} 5$ & GCTACAAAATCACTGCTAAG & Sequence pseudogene \\
\hline $512 \mathrm{gw} 7$ & CAGAGGACATTTTCACAAG & Sequence pseudogene \\
\hline $512 \mathrm{gw} 8$ & GCAAGGAGATCAAATTAGTC & Sequence pseudogene \\
\hline $512 \mathrm{gw} 9$ & TGGTAAGAGTATAACAGCAA & Sequence pseudogene \\
\hline $512 \mathrm{gw} 10$ & TTGCTGTTATACTCTTACCA & Sequence pseudogene \\
\hline $512 \mathrm{gw} 11$ & CAATATTGTCACCTAGCAGA & Sequence pseudogene \\
\hline $512 \mathrm{gw} 12$ & CCCATGGACAGAGGAGCC & Sequence pseudogene \\
\hline $512 \mathrm{gw} 13$ & GTAACACAACCAAAATGCAA & Sequence pseudogene \\
\hline $512 \mathrm{gw} 14$ & GACTCCAGCTTGCACTTTAT & Sequence pseudogene \\
\hline BvEx31499r & CTCAGTATGCTAATGCCC & Sequence pseudogene \\
\hline BvEx31907r & GGCAGCCTTCCATTTTGT & Sequence pseudogene \\
\hline 4222T7gw1 & TATAAAAACAGGTAATGCATT & Sequence pseudogene \\
\hline BvEx33444r & GAGAAGATGCTACAACTGAT & Sequence pseudogene \\
\hline BvEx33840r & GAAAAGACTGTGGGGTGA & Sequence pseudogene \\
\hline BvEx34523r & CTTTGCATGTACTTGTTTTG & Sequence pseudogene \\
\hline Prion exon 1 & DigN-GCAGAGCTGAGAGCGTCTTC ${ }^{\mathrm{a}}$ & Probe \\
\hline $\mathrm{T} 3$ & ATTAACCCTCACTAAAGGGA & Sequencing primer \\
\hline T7 & TAATACGACTCACTATAGGG & Sequencing primer \\
\hline
\end{tabular}

${ }^{a}$ Denotes $5^{\prime}$ digoxigenin label.

with $M b o$ I, size selected on pulsed field gels, ligated into the Bacterial Artificial Chromosome (BAC) vector pECBAC1 and electroporated into Escherichia coli strain DH10B (New England Biolabs). The average insert size was $55 \mathrm{~kb}$. Approximately $3 \times 10^{5}$ colony forming units (5.5 genome equivalents) were plated on nylon filters. Duplicate filter lifts were made from the Master plate and prepared for hybridization using standard methods (Sambrook et al., 1989). Filters were hybridized with a digoxigenin-labeled probe corresponding to the coding region of the mule deer PRNP gene prepared using primer pair 199/202. Generation and digoxigenin labeling of the probe, hybridization and detection were as recommended by the manufacturer of the PCR labeling kit (Roche). High stringency wash conditions were as follows: two washes in $2 \times \mathrm{SSC}, 0.1 \% \mathrm{SDS}(\mathrm{w} / \mathrm{v})$ at room temperature, one wash in the same buffer at $65{ }^{\circ} \mathrm{C}$, and a final wash in $0.2 \times \mathrm{SSC}$, $0.1 \% \operatorname{SDS}(\mathrm{w} / \mathrm{v})$ at $65{ }^{\circ} \mathrm{C}$. All washes were $15 \mathrm{~min}$. Detection of signal was according to the manufacturer's directions (Roche). Positive clones were subjected to two additional rounds of screening until "colony pure" pos- itives were obtained. After the tertiary screen, 25 clones were obtained.

\subsection{Southern analysis}

DNA prepared from each positive BAC clone (Birnboim and Doly, 1979) or mule deer genomic DNA was digested with EcoRI, separated on a $0.7 \%$ agarose gel, transferred to a nylon membrane and hybridized with the mule deer exon 3 probe as described above. The filter was stripped and re-probed with digoxigenin labeled oligonucleotide probe corresponding to the cattle and sheep PRNP gene exon 1 (since this region was previously unknown in mule deer). Filters were hybridized in $5 \times \mathrm{SSC}, 1 \%$ Blocking Reagent (Roche), $0.1 \% N$-lauroylsarkosine, $0.02 \%$ SDS, $0.1 \mathrm{mg} / \mathrm{ml}$ poly(A), and $40 \mathrm{pmol} / \mathrm{ml}$ of digoxygenin labeled oligonucleotide at $48{ }^{\circ} \mathrm{C}$. Filters were washed twice in $2 \times \mathrm{SSC}, 0.1 \% \mathrm{SDS}$, and twice in $0.2 \times$ SSC, $0.1 \%$ SDS; each wash was $5 \mathrm{~min}$ at $48{ }^{\circ} \mathrm{C}$. Detection of signal was according to the manufacturer's directions (Roche). 


\subsection{BAC sequencing}

BAC clone \#50 was fragmented using the Hydroshear (GeneMachines) and fragments of $3 \mathrm{~kb}$ were cloned in the pCRScript vector. Three 96 well plates of clones were sequenced from both ends using the T3 and T7 primers, and two additional 96 well plates of clones were sequenced from one end using the T7 primer. Data were assembled and analyzed using Sequencher (Genecodes) and PHRED and PHRAP software (University of Washington). When required, gene walking or direct BAC sequencing was performed to ensure a minimum of $2 \times$ coverage with an overall average of $6 \times$ coverage. The finished sequence contains 65,476 bp (Genbank accession no. AY330343). BAC clone \#39 was partially sequenced using primers designed against the prion gene-coding region, (see Table 1 for primers) or the bovine prion gene sequence (accession no. AJ298878). A total of 4970 bp (accession no. AY371694) were sequenced from BAC \#39, of which, $4268 \mathrm{bp}$ correspond to the pseudogene and flanking repeats. Two additional rounds of gene walking completed the sequence. BAC sequencing was performed at Amplicon Express (Pullman, WA).

\section{Results and discussion}

\subsection{Heterogeneity in the ORF of the PRNP gene of mule deer}

DNA from 145 mule deer was analyzed for coding polymorphisms in the region between the signal peptide cleavage site and the GPI anchor cleavage site, or the full length ORF. Of 145 mule deer, 144 were heterozygous for a coding change (agc to aac, Serine $[\mathrm{S}]$ to Asparagine [N]) at codon 138 with non-coding polymorphisms at codons 139 (agg/aga) and 156 (aat/aac). A gene duplication event was the most likely explanation for this finding, although lethal mutations in both homozygous states (138NN and 138SS) could not be ruled out even though one adult with the 138SS genotype was identified (see Section 3.4). Cloning and sequence analysis of PCR amplified products demonstrated that individual mule deer samples encoded two, three, or four PRNP alleles, with either one or two alleles invariably encoding $138 \mathrm{~S}$ and one or two alleles invariably encoding 138 N. These individual deer with three or four alleles confirmed that a gene duplication event had occurred. All alleles contained the full length ORF, encoding 256 amino acids.

\subsection{Organization and allelic variation of the mule deer PRNP gene}

A mule deer genomic BAC library was prepared from one mule deer and screened with a probe corresponding to the ORF in exon 3. Analysis of the prion gene ORF positive clones from the mule deer genomic BAC library revealed the presence of a functional gene and at least one processed pseudogene (Fig. 1). Clone \#50, identified by hybridization with both the exon 1 and exon 3 probes (Fig. 2), was sequenced to derive the entire functional gene. The functional gene is $19.9 \mathrm{~kb}$ in length and contains three exons, similar to that previously reported for the bovine, human, murine, and ovine PRNP (Lee et al., 1998; Hills et al., 2001). Intron-exon boundaries, inferred from the previously published bovine and ovine PRNP sequences and confirmed by sequencing of cDNA clones, conform to the GTAG splice acceptor-donor rules (Senapathy et al., 1990). Mule deer exons 1, 2, and 3 are 54, 98 and 4083 nucleotides in length, respectively. The introns are 2407 and 13,252 nucleotides in length (Fig. 1). Sequence identity between the cattle and mule deer PRNP genes was 92.5\%, 93.9\%, and 93.2\% for exons 1, 2 and 3, respectively. Sequence identity between the sheep and mule deer exons was $88.9 \%, 93.9 \%$, and $96.8 \%$. The $3^{\prime}$ UTR of exon 3 contains a mariner transposase relic previously described for the ovine and bovine genes (Lee et al., 1998). Amino acid identity and similarity of the coding region in exon 3 between mule deer and bovine prion proteins was $94.7 \%$ and $95.1 \%$, respectively, and between mule deer and sheep, $98.0 \%$ and $98.8 \%$.

\section{Functional Gene}

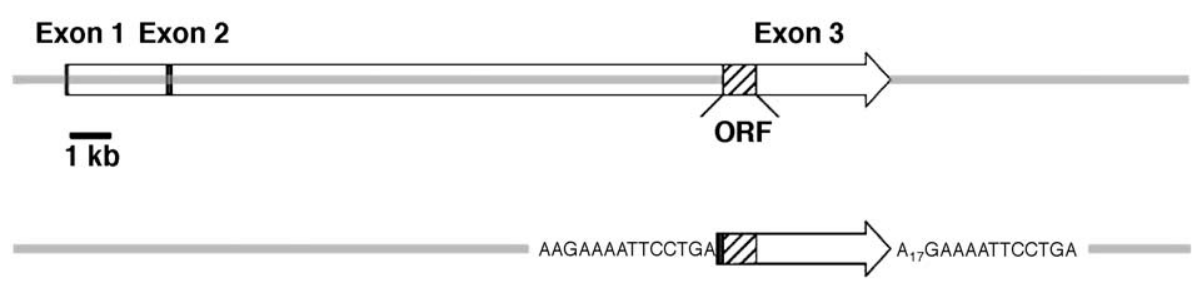

\section{Pseudogene}

Fig. 1. Schematic representation of the full length functional gene and the pseudogene. Exons of the functional gene are marked. The ORF is striped. Introns are represented within the arrow demarking the gene. The arrangement of functional gene sequences in the pseudogene is shown. The sequences of the direct repeats are shown flanking the pseudogene. 


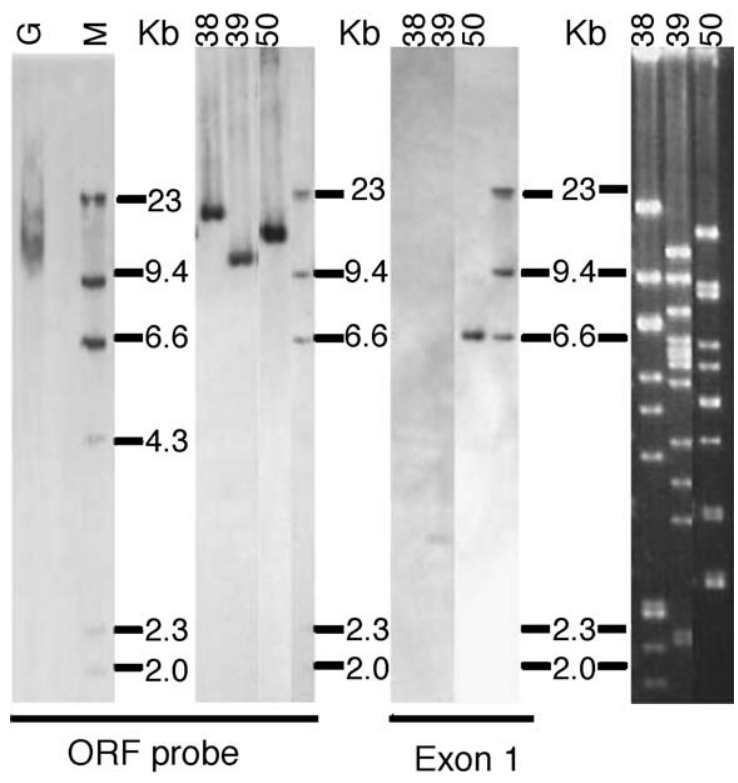

Fig. 2. Southern analysis of mule deer genomic DNA and PRNP BAC clones. Lane $\mathrm{G}$ contains mule deer genomic DNA digested with the restriction endonuclease EcoRI and hybridized with a PRNP gene ORF probe. Lane $\mathrm{M}$ contains $\lambda$ HindIII digoxigenin labeled size standards, and molecular weights are indicated. Lanes 38, 39 and 50 contain BAC clones digested with EcoRI. The ethidium bromide stained gel is shown on the far right. The genomic and BAC blots were hybridized with the mule deer PRNP ORF probe, and subsequently, the BAC blot was stripped and rehybridized with the exon 1 probe.

Primer set 223/224, flanking the mule deer PRNP ORF, were used to specifically amplify the functional gene. Sequence analysis of PCR products from homozygous animals and cloning of amplicons from heterozygotes confirmed that there are three alleles of the functional gene, with coding changes at codons 20 (Aspartic acid [D]/ Glycine [G]) and 225 (S/Phenylalanine [F]) and additional non-coding changes at codons 131, 146, 156, 202, and 206 (Fig. 3).

\subsection{Cloning, characterization, and allelic variation of the processed pseudogene}

BAC Clone \#39 was identified by hybridization to the PRNP ORF probe but did not hybridize to the exon 1 probe, thereby identifying the PRNP pseudogene (Fig. 2). The processed pseudogene in this clone had the classic hallmarks of retroelements (Vanin, 1985; Mighell et al., 2000) with the presence of a $3^{\prime}$ poly(A) tract, the lack of introns, flanking direct repeats (5'[AA]GAAAATTCCTGAGA $3^{\prime}$ ) (Fig. 1), and lack of an expressed mRNA as evidenced by failure to detect pseudogene-specific sequences in cDNA prepared from peripheral blood leukocytes (data not shown). The pseudogene was truncated at the $5^{\prime}$ end of exon 1 by 25 bp when aligned with exon 1 of the functional gene and contained $4223 \mathrm{bp}$ (not including the poly A tract and direct repeat). The cloned pseudogene allele (from BAC \#39) encoded $33 \mathrm{bp}$ substitutions throughout the pseudogene regions when compared to the cloned functional gene (from BAC \#50), with six of these contained in the coding region. Additionally, the cloned pseudogene allele contained three insertions and three deletions relative to the functional gene, all in the $3^{\prime}$ UTR.

Southern analysis of EcoRI digested mule deer genomic DNA hybridized with the PRNP ORF probe revealed three hybridizing bands of 9.8, 12.2 and $20 \mathrm{~kb}$, the smallest band corresponding to the functional gene and the larger bands corresponding to the pseudogene (Fig. 2). This hybridization pattern was seen in all mule deer genomic DNA samples tested (data not shown). BAC clones from the mule deer library contained representatives of each of the hybridizing bands. The pseudogene in clone \#39, contained a 12.2 $\mathrm{kb}$ hybridizing EcoRI fragment, and was sequenced as described above. DNA from clones \#30, \#32, \#35, and \#38, each containing a $20 \mathrm{~kb}$ hybridizing EcoRI fragment, was amplified with a pseudogene-specific primer pair (369/ 224) that flanks the ORF of exon 3. In addition, the insertion site of the pseudogene was determined for each of these clones by direct sequencing of the BAC DNA using a reverse primer (primer 350) to determine the sequence of the mule deer DNA immediately upstream from the $5^{\prime}$ repeat sequence. Sequences of the 369/224 amplicon and the pseudogene-flanking region in these four clones were identical to the pseudogene sequences in clone \#39 and variation in the EcoRI fragment length was attributed to restriction sites flanking the pseudogene, i.e. a restriction fragment length polymorphism. Therefore, it is concluded that there is a single pseudogene in mule deer.

Pseudogene allelic variants were identified by sequence analysis of amplicons generated from genomic DNA using primer pair 369/224. The pseudogene alleles invariably encoded N (aac) at codon 138, but varied at codons 65 (gga to gaa, $\mathrm{G}$ to Glutamic acid [E]) and 151 (cgt to tgt, Arginine [R] to Cysteine [C]). Cloning and sequence analysis confirmed the sequence of three alleles of the

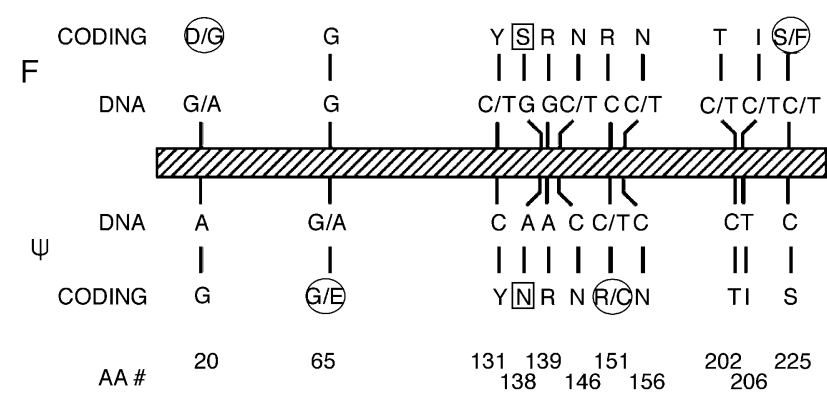

Fig. 3. Schematic diagram of potential polymorphisms found in the PRNP functional gene and pseudogene. The striped bar indicates the PRNP ORF. Polymorphisms found in the functional gene (F) or pseudogene $(\psi)$ are shown above or below the striped bar as indicated. The four polymorphic codons are circled. The codon $(138 \mathrm{~S} / \mathrm{N})$ that is uniformly different between the pseudogene and the functional gene is boxed. The polymorphisms occur at nucleotide positions 59, 194, 393, 412, 418, 438, 451, 466, 606, 618 and 674 which correspond to amino acid (AA) positions 20, 65, 131, 138, 139, $146,151,156,202,206$, and 225 shown in the figure. 
pseudogene, identified as GR, GC, and ER from the deduced amino acid sequences, and an additional noncoding change at codon 139 (Fig. 3). The polymorphism at codon 138 was noted in two previous studies (Cervenáková et al., 1997; Heaton et al., in press), although the $\mathrm{N}$ allele was considered to be a functional allele in those studies.

\subsection{Molecular evolution of the mule deer pseudogene}

The mule deer pseudogene carries the classic hallmarks of a retrotransposable element, duplicated DNA copies of mRNA formed by long interspersed nuclear elements (LINEs) which transpose themselves as well as other RNAs through an endogenous reverse transcriptase (Mighell et al., 2000). Premature dissociation of the LINE reverse transcriptase occurs frequently, resulting in truncation of the $5^{\prime}$ end of the gene (Luan et al., 1993), as observed in this case. The sequences immediately upstream from the repeat region were determined by direct sequencing of BAC clones encoding the pseudogene. The basic local alignment search tool (BLAST) algorithm was used to demonstrate that the mule deer pseudogene is flanked by sequences similar to the Bov2-LINE, sharing 87\% identity over 172 bp (see Genbank AJ421481). Bov2-Line is a widespread transposable element found in all pecoran ruminants (Kordis and Gubensek, 1999). Using the pseudogene-specific primer pair, the pseudogene was detected in both subspecies of New World deer $O$. hemionus (mule deer and black-tailed deer). The pseudogene was not found in samples from the three species of Old World Deer examined (Rocky Mountain elk, reindeer, and fallow deer). The absence of a positive PCR result for the pseudogene in Old World deer could be the result of sequence divergence at the primer sites or a low pseudogene frequency in these species. Alternatively, establishment of the pseudogene may have occurred after divergence between Old World and New World deer during the late Miocene/early Pliocene epochs, $\sim 5$ million years ago (Wallmo, 1981; Hassanin and Douzery, 2003). The only other report of a $P R N P$ gene pseudogene is in the anteater (Van Rheede et al., 2003), an Old World edentate. Interestingly, the single animal that typed as a 138S homozygote was found not to have the pseudogene. This individual may be the result of a novel deletion among mule deer of the region containing the pseudogene.

\subsection{PRNP and pseudogene alleles in mule deer with $C W D$}

Primer pairs specific for the functional gene (primer pair 223/224) and the pseudogene (primer pair 369/224) were used to re-assign the alleles from $47 \mathrm{CWD}$-positive mule deer as either functional alleles or pseudogene alleles (Table 2). Alleles were grouped by the deduced amino acid substitutions at codons $20(\mathrm{D} / \mathrm{G})$ and $225(\mathrm{~S} / \mathrm{F})$ in the functional gene and codons $65(\mathrm{G} / \mathrm{E})$ and $156(\mathrm{R} / \mathrm{C})$ in the pseudogene. Functional diploid genotypes in mule deer with CWD
Table 2

Functional and pseudogene alleles in mule deer with chronic wasting disease

\begin{tabular}{|c|c|c|c|c|c|c|c|}
\hline \multirow{2}{*}{$\begin{array}{l}\text { Functional } \\
\text { diploid } \\
\text { genotype }^{\text {a }}\end{array}$} & \multicolumn{6}{|c|}{ Pseudogene diploid genotype $^{\mathrm{b}}$} & \multirow{2}{*}{$\begin{array}{l}\text { Total } \\
(\%)\end{array}$} \\
\hline & GR-GR & ER-ER & GR-ER & GR-GC & GC-GC & GC-ER & \\
\hline DS-DS & 18 & 1 & 9 & 4 & 0 & 2 & $34(72.3)$ \\
\hline DS-DF & 0 & 0 & 0 & 2 & 0 & 2 & $4(8.5)$ \\
\hline DS-GS & 3 & 0 & 1 & 0 & 0 & 4 & $8(17.0)$ \\
\hline GS-GS & 0 & 1 & 0 & 0 & 0 & 0 & $1(2.1)$ \\
\hline $\begin{array}{l}\text { DF-DF } \\
\text { or }\end{array}$ & 0 & 0 & 0 & 0 & 0 & 0 & $0(0)$ \\
\hline
\end{tabular}

${ }^{\mathrm{a}}$ Functional gene alleles are grouped by the deduced amino acid residues at codons 20 and 225 .

${ }^{\mathrm{b}}$ Pseudogene alleles are grouped by the deduced amino acid residues at codons 65 and 151 .

included animals homozygous for the predominant allele 20D225S $(n=34)$ and the relatively rare allele 20G225S $(n=1)$ and deer heterozygous at codon $20(n=8)$ and codon $225(n=4)$. Four of the six possible peptide combinations deduced from the functional gene sequences were found in the CWD-positive population, demonstrating that deer with the genotypes DS-DS, DS-DF, DS-GS, and GS-GS are susceptible to CWD. The alleles encoding functional gene $20 \mathrm{D} 225 \mathrm{~F}$ and pseudogene $65 \mathrm{G} 151 \mathrm{C}$ were rare in this population, and determination of the relative susceptibility or resistance of deer with these alleles will require considerably larger sample sizes from free ranging populations or experimental exposure of captive deer.

\subsection{Conclusions}

In summary, we have delineated the genomic organization of the mule deer PRNP gene and identified a processed pseudogene. Our results show that the functional gene encodes a limited number of alleles, and four out of the six possible diploid genotypes (grouped by deduced amino acid changes in the ORF) were found in a sample of 47 mule deer with CWD. The presence of an unexpressed pseudogene is unlikely to affect the outcome of this protein-only prion disorder but contributes to the extensive heterogeneity noted when sequence data are derived from primer pairs amplifying the ORF of the functional gene and the pseudogene simultaneously. Therefore, selection of primers specific for the functional gene is critical for subsequent largescale studies of mule deer PRNP genotypes directed at identifying alleles associated with resistance to CWD.

\section{Acknowledgements}

We thank Linda Hamburg and Shannon Munro, USDA, ARS, and Jerry Higbee, Amplicon Express, Pullman, WA, for expert technical assistance with PCR amplification and sequencing, and David Herndon and Lowell Kappmeyer, USDA, ARS, for primer design and data analysis. This work 
was supported by a grant from the Agricultural Research Service, U.S. Department of Agriculture (CWU 534832000-021-00D).

\section{References}

Belay, E.D., Gambetti, P., Schonberger, L.B., Parchi, P., Lyon, D.R., Capellari, S., McQuiston, J.H., Bradley, K., Dowdle, G., Crutcher, J.M., Nichols, C.R., 2001. Creutzfeldt-Jakob disease in unusually young patients who consumed venison. Arch. Neurol. 58, 1673-1678.

Birnboim, H.C., Doly, J., 1979. A rapid alkaline extraction procedure for screening recombinant plasmid DNA. Nucleic Acids Res. 7, $1513-1523$

Birren, B., Green, E.D., Klapholz, S., Myers, R.M., Roskams, J. (Eds.), 1997. Genome Analysis: A Laboratory Manual. Cold Spring Harbor Laboratory Press, United States of America, pp. 136-138. Chapter 2.

Bolton, D.C., McKinley, M.P., Prusiner, S.B., 1982. Identification of a protein that purifies with the scrapie prion. Science 218, 1309-1311.

Cervenáková, L., Rohwer, R., Williams, S., Brown, P., Gajdusek, D.C., 1997. High sequence homology of the PrP gene in mule deer and Rocky Mountain elk. Lancet 350, 219-220.

Dawson, M., Hoinville, L.J., Hosie, B.D., Hunter, N., 1998. Guidance on the use of PrP genotyping as an aid to the control of clinical scrapie. Vet. Rec. 142, 623-625.

Hassanin, A., Douzery, E.J., 2003. Molecular and morphological phylogenies of ruminantia and the alternative position of the moschidae. Syst. Biol. 52, 206-228.

Heaton, M.P., Leymaster, K.A., Freking, B.A., Hawk, D.A., Keele, J.W., Snelling, W.M., Fox, J.M., Chitko-McKown, C.G., Laegreid, W.W., in press. Prion gene sequence variation within diverse groups of U.S. sheep, beef cattle, and deer. Mamm. Genome, 14.

Hills, D., Comincini, S., Schlaepfer, J., Dolf, G., Ferretti, L., Williams, J.L., 2001. Complete genomic sequence of the bovine prion gene (PRNP) and polymorphism in its promoter region. Anim. Genet. 32, 231-232.

Hunter, N., 1997. PrP genetics in sheep and the implications for scrapie and BSE. Trends Microbiol. 5, 331-334.

Hunter, N., Goldmann, W., Marshall, E., O’Neill, G., 2000. Sheep and goats: natural and experimental TSEs and factors influencing incidence of disease. Arch. Virol. 16, 181-188.

Kordis, D., Gubensek, F., 1999. Molecular evolution of Bov-B LINEs in vertebrates. Gene 238, 171-178.

Lee, I.Y., Westaway, D., Smit, A.F., Wang, K., Seto, J., Chen, L., Acharya, C., Ankener, M., Baskin, D., Cooper, C., Yao, H., Prusiner, S.B., Hood, L.E., 1998. Complete genomic sequence and analysis of the prion protein gene region from three mammalian species. Genome Res. 8, $1022-1037$.

Luan, D.D., Korman, M.H., Jakubczak, J.L., Eickbush, T.H., 1993. Reverse transcription of R2Bm RNA is primed by a nick at the chromosomal target site: a mechanism for non-LTR retrotransposition. Cell $72,595-605$.

Mighell, A.J., Smith, N.R., Robinson, P.A., Markham, A.F., 2000. Vertebrate pseudogenes. FEBS Lett. 468, 109-114.

Miller, M.W., Williams, E.S., 2002. Detection of PrP(CWD) in mule deer by immunohistochemistry of lymphoid tissues. Vet Rec. 151, 610-612.

Miller, M.W., Williams, E.S., McCarty, C.W., Spraker, T.R., Kreeger, T.J., Larsen, C.T., Thorne, E.T., 2000. Epizootiology of chronic wasting disease in free-ranging cervids in Colorado and Wyoming. J. Wildl. Dis. 36, 676-690.

O’Rourke, K.I., Besser, T.E., Miller, M.W., Cline, T.F., Spraker, T.R.,
Jenny, A.L., Wild, M.A., Zebarth, G.L., Williams, E.S., 1999. PrP genotypes of captive and free-ranging Rocky Mountain elk (Cervus elaphus nelsoni) with chronic wasting disease. J. Gen. Virol. 80, $2765-2769$.

O’Rourke, K.I., Zhuang, D., Lyda, A., Gomez, G., Williams, E.S., Tuo, W.B., Miller, M.W., 2003. Abundant $\mathrm{PrP}^{\mathrm{CWD}}$ in tonsil from mule deer with preclinical chronic wasting disease. J. Vet. Diagn. Invest. 15, $320-323$

Prusiner, S.B., 1982. Novel proteinaceous infectious particles cause scrapie. Science 216, 136-144.

Puoti, G., Rossi, G., Giaccone, G., Awan, T., Lievens, P.M.J., Defanti, C.A., Tagliavini, F., Bugiani, M., 2000. Polymorphism at codon 129 of PRNP affects the phenotypic expression of Creutzfeldt-Jakob disease linked to E200K mutation. Ann. Neurol. 48, 269-270.

Raymond, G.J., Bossers, A., Raymond, L.D., O’Rourke, K.I., McHolland, L.E., Bryant III, P.K., Miller, M.W., Williams, E.S., Smits, M., Caughey, B., 2000. Evidence of a molecular barrier limiting susceptibility of humans, cattle and sheep to chronic wasting disease. EMBO J. 19, $4425-4430$.

Sambrook, J., Fritsch, E.E., Maniatis, T., 1989. IN Molecular Cloning: A Laboratory Manual. Cold Spring Harbor Laboratories, 2nd ed. Cold Spring Harbor, NY.

Senapathy, P., Shapiro, M.B., Harris, N.L., 1990. Splice junctions, branch point sites, and exons: sequence statistics, identification, and applications to genome project. Methods Enzymol. 183, 252-278.

Spraker, T.R., Zink, R.R., Cummings, B.A., Sigurdson, C.J., Miller, M.W., O'Rourke, K.I., 2002. Distribution of protease-resistant prion protein and spongiform encephalopathy in free-ranging mule deer (Odocoileus hemionus) with chronic wasting disease. Vet. Pathol. 39, 546-556.

Vanin, E.F., 1985. Processed pseudogenes: characteristics and evolution. Annu. Rev. Genet. 19, 253-272.

Van Rheede, T., Smolenaars, M.M., Madsen, O., De Jong, W.W., 2003. Molecular evolution of the mammalian prion protein. Mol. Biol. Evol. 20, $111-121$.

Wallmo, O.C. (Ed.), 1981. Mule and black-tailed deer of North America. University of Nebraska Press, Lincoln, pp. 157-159. Chapter 5.

Ward, J.W. (Ed.), 2003. Fatal degenerative neurologic illnesses in men who participated in wild game feasts-Wisconsin, 2002. Morb. Mortal. Wkly. Rep. vol. 52, 125-127.

Westaway, D., Zuliani, V., Cooper, C.M., Da Costa, M., Neuman, S., Jenny, A.L., Detwiler, L., Prusiner, S.B., 1994. Homozygosity for prion protein alleles encoding glutamine-171 renders sheep susceptible to natural scrapie. Genes Dev. 8, 959-969.

Wild, M.A., Spraker, T.R., Sigurdson, C.J., O’Rourke, K.I., Miller, M.W., 2002. Preclinical diagnosis of chronic wasting disease in captive mule deer (Odocoileus hemionus) and white-tailed deer (Odocoileus virginianus) using tonsillar biopsy. J. Gen. Virol. 83, 2629-2634.

Williams, E.S., Young, S., 1980. Chronic wasting disease of captive mule deer: a spongiform encephalopathy. J. Wildl. Dis. 16, 89-98.

Williams, E.S., Young, S., 1982. Spongiform encephalopathy of Rocky Mountain elk. J. Wildl. Dis. 18, 465-471.

Williams, E.S., Young, S., 1993. Neuropathology of chronic wasting disease of mule deer (Odocoileus hemionus) and elk (Cervus elaphus nelsoni). Vet. Pathol. 30, 36-45.

Williams, E.S., Miller, M.W., 2002. Chronic wasting disease in deer and elk in North America. Rev. Sci. Tech. 21, 305-316

Windl, O., Dempster, M., Estibeiro, J.P., Lathe, R., De Silva, R., Esmonde, T., Will, R., Springbett, A., Campbell, T.A., Sidle, K.C., Palmer, M.S., Collinge, J., 1996. Genetic basis of Creutzfeldt-Jakob disease in the United Kingdom: a systematic analysis of predisposing mutations and allelic variation in the PRNP gene. Hum. Genet. 98, 259-264. 